\title{
Analytical Method Development and Validation of Etanercept by UV and RP-UFLC Methods
}

\author{
Husna Kanwal Qureshi, Ciddi Veeresham*, Chinta Srinivas \\ Department of Pharmaceutical Analysis, University College of Pharmaceutical Sciences, Kakatiya University, Warangal, India \\ Email: *ciddiveeresham@yahoo.co.in
}

How to cite this paper: Qureshi, H.K., Veeresham, C. and Srinivas, C. (2021) Analytical Method Development and Validation of Etanercept by UV and RP-UFLC Methods. American Journal of Analytical Chemistry, 12, 493-505.

https://doi.org/10.4236/ajac.2021.1212031

Received: November 29, 2021

Accepted: December 27, 2021

Published: December 30, 2021

Copyright $\odot 2021$ by author(s) and Scientific Research Publishing Inc. This work is licensed under the Creative Commons Attribution International License (CC BY 4.0).

http://creativecommons.org/licenses/by/4.0/

\begin{abstract}
The research work was carried out using Ultraviolet (UV) - visible spectroscopy and Reverse Phase-Ultra Fast Liquid Chromatography (RP-UFLC) for establishing novel methods for the analysis and quantification of Biosimilar drug, Etanercept. The maximum absorbance of Etanercept was found to be $215 \mathrm{~nm}$ and it obeyed Beer-Lamberts law in the range of 5 to $200 \mu \mathrm{g} / \mathrm{ml}$ and 1 to 32 $\mu \mathrm{g} / \mathrm{ml}$ for UV and RP-UFLC, respectively. The correlation coefficient $\left(\mathrm{r}^{2}\right)$ value was found to be between 0.999 and 0.9995 . All the validation parameters like linearity, accuracy, and precision, Limit of Detection (LOD), Limit of Quantitation (LOQ) and Robustness were found to be within acceptance criteria as per ICH guidelines. The results of accuracy studies (99.0\% to $100.38 \%$ ) indicated the methods to be accurate. The RSD \% for interday and intraday precision studies was found to be less than $2 \%$. Robustness and ruggedness were expressed in terms of RSD \% which were also in the specified limits. LOD and LOQ of proposed method was calculated and found to be 1.257 and 3.809 $\mu \mathrm{g} / \mathrm{ml}$ by $\mathrm{UV}$, and $0.1073 \mu \mathrm{g} / \mathrm{ml}$ and $0.3251 \mu \mathrm{g} / \mathrm{ml}$ by RP-UFLC method, respectively. The developed methods were observed to be simple, rapid and costefficient. It can be easily applied for the estimation of Etanercept in the marketed formulations and for routine analysis of the Biosimilar drug.
\end{abstract}

\section{Keywords}

Biosimilars, Etanercept, Etacept ${ }^{\circledR}$, RP-UFLC, UV Spectroscopy, Validation

\section{Introduction}

Biosimilars are similar but not identical versions of a commercial originator/ innovator biotherapeutic that is being produced by different pharmaceutical manufacturers after patent and exclusivity expiration [1]. As per European Medicine Agency (EMA), Biosimilar drugs should exhibit similarity in terms of structure, 
post-translational modifications, glycosylation and biological indications. Examples of Biosimilars of Etanercept like SB4, GP2015, HD203, LBEC0101, YLB113, etc.

The dawn of biological drugs has renewed the management and treatment of immune-mediated inflammatory diseases [2] [3] [4] [5] [6]. In order to target the pathogenic process of autoimmune rheumatic diseases, a class of biological Disease-Modifying Antirheumatic Drugs (DMARDs) has been introduced [3]. Examples include Tumor Necrosis Factor (TNF) inhibitors like Etanercept, Infliximab, Adalimumab, Golimumab and Certolizumab Pegol [7] [8]. It has revolutionized the treatment of rheumatic diseases [9] [10] [11].

Etanercept is a dimeric fusion protein-drug produced by recombinant DNA technology from the Chinese Hamster Ovary expression system [8] [12] [13] (Figure 1). It consists of 934 amino acids with a molecular weight of $150 \mathrm{kDa}$ [14]. Its function is similar to the activity of naturally occurring soluble TNF alpha receptors [12]. It competes with TNF alpha cell membrane receptors preventing them from interacting with the pro-inflammatory cytokine. Thus, it decreases the local and systemic production of pro-inflammatory cytokines and subsequent effects [15]. It is used for the following indications like psoriatic arthritis, axial spondyloarthritis, plaque psoriasis, juvenile idiopathic arthritis/poly articular course juvenile rheumatoid arthritis and ankylosing spondylitis.

Literature survey [16] [17] [18] [19] revealed the availability of various methods and techniques used for comparative studies between innovator drugs and new biosimilars.

The literature search also revealed that there are no publications available on method development and validation on Etanercept by UV and RP-HPLC, so far to the knowledge of authors. Ultraviolet (UV) spectroscopy has the precedence

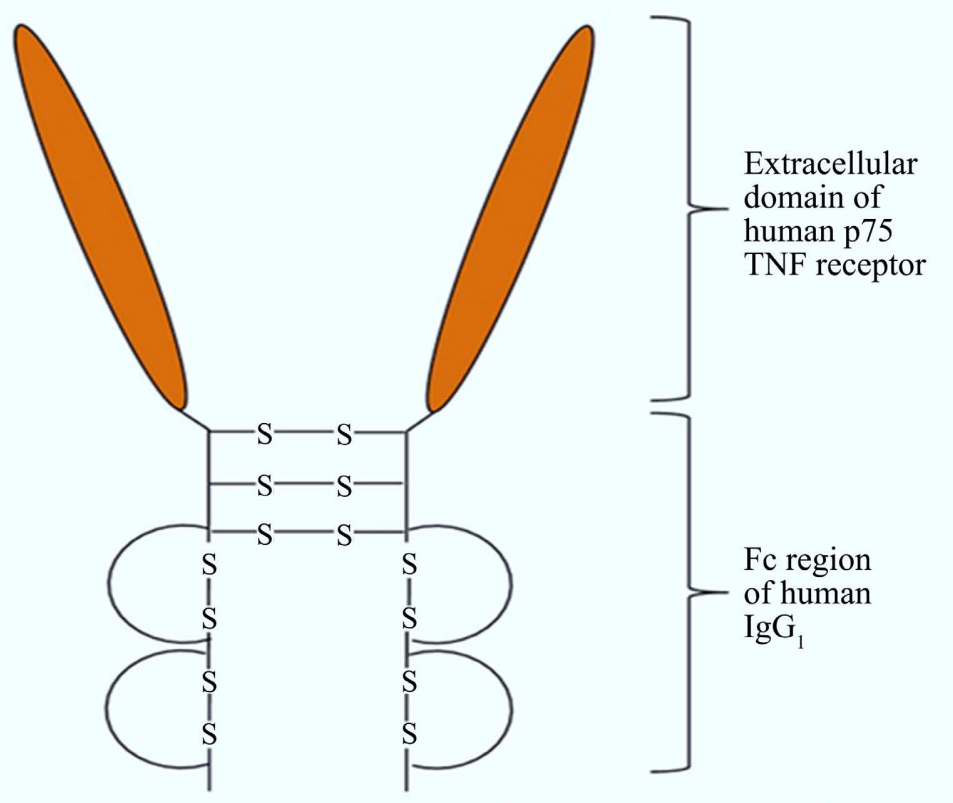

Figure 1. Structure of Etanercept. 
of being simple, rapid and cost-effective. In view of this, the present paper aimed at the analytical method development along with validation of Etanercept by using UV spectroscopy and RP-UFLC.

\section{Materials and Methods}

\subsection{Instrumentation}

A Shimadzu UV1800 Spectrophotometer ENG 240V (Serial number: A11635101549) with Quartz cells of $1 \mathrm{~cm}$ path length and Shimadzu Prominence LC-20AD UFLC with UV detection (Model: RF-20A; Serial number:

L20495001669) from Shimadzu Corporation (manufacturer), were used for the analysis. Lab solutions software for both instruments were used for analysis. Weighing balance (Shimadzu, Model: AUX 220) with internal automated calibration mode was used for the accurate weighing purpose.

\subsection{Chemicals and Reagents}

Etanercept reference standard was purchased from European Medicine Agency (EMEA), Strasbourg, France. Etacept ${ }^{\circledR}$, marketed formulation was obtained as gift sample from Cipla Limited, Mumbai. Double distilled water was obtained from Merck Millipore Direct Q UV water system.

\section{Methodology}

\subsection{Determination of Wavelength $\left(\lambda_{\max }\right)$}

The diluted standard solution $(500 \mu \mathrm{g} / \mathrm{ml})$ was scanned from 800 - $200 \mathrm{~nm}$ using UV/VIS Spectrophotometer, with double distilled water as blank. After acquiring the spectrum, $\lambda_{\max }$ was identified. The above method was repeated thrice. The method was developed at room temperature $\left(25^{\circ} \mathrm{C}\right)$.

\subsection{RP-UFLC Chromatographic Conditions}

The reverse-phase chromatographic analysis was done by using Phenomenex C18 column $(25 \mathrm{~cm} \times 0.46 \mathrm{~cm}$ internal diameter) $5 \mu, 100 \AA$ analytical column with $0.1 \mathrm{M}$ Potassium dihydrogen Ortho phosphate buffer (pH-5.5) and Acetonitrile (60:40 $\mathrm{v} / \mathrm{v}$ ) as mobile phase in binary elution. The method was run at $1 \mathrm{ml} / \mathrm{min}$ at 215 $\mathrm{nm}$.

\subsection{Preparation of Working Standard Drug Solution}

For preparing working standard solutions, Reference standard Etanercept (5 mg) was accurately weighed and transferred into the $(5 \mathrm{ml})$ Volumetric Flask and dissolved properly to get $1 \mathrm{mg} / \mathrm{ml}$ stock solution. 5, 25, 50, 100, 150 and $200 \mu \mathrm{g} / \mathrm{ml}$ were prepared from the standard stock solution for UV analysis and 1, 2, 4, 8, 16 and $32 \mu \mathrm{g} / \mathrm{ml}$ were prepared for RP-UFLC method.

\subsection{Preparation of Calibration Curve}

The Calibration curve was developed by using 6 different dilutions prepared 
from standard solution (5 to $200 \mu \mathrm{g} / \mathrm{mL}$ strength for UV and 1 to $32 \mu \mathrm{g} / \mathrm{ml}$ for RP-UFLC). Absorbance (UV) and peak areas (RP-UFLC) of every calibration standard were estimated at $\lambda_{\max }$ of $215 \mathrm{~nm}$. The calibration curves representing Absorbance/Peak areas vs concentrations were plotted using Microsoft Excel 2013.

\section{Method Validation}

Developed UV and RP-UFLC methods were validated as per specifications from International Conference on Harmonization (ICH) for analytical validation. The methods were analyzed for the parameters like linearity, accuracy, precision. robustness, ruggedness, LOD and LOQ.

\subsection{System Suitability}

For evaluating the suitability of UFLC system and developed procedure, Etanercept standard solution of $10 \mu \mathrm{g} / \mathrm{ml}$ concentration was prepared and about $20 \mu \mathrm{l}$ was injected into the UFLC system. Then the chromatogram was recorded.

\subsection{Linearity}

For demonstrating linearity, six different concentrations were analyzed each for the optimized methods. 5, 25, 50, 100, 150 and $200 \mu \mathrm{g} / \mathrm{ml}$ were concentrations for UV and 1, 2, 4, 8, 16 and $32 \mu \mathrm{g} / \mathrm{ml}$ concentrations for RP-UFLC. After analyzing calibration standards, calibration curve in terms of absorbance vs. concentration was developed for UV method and Peak area vs. concentration for RPUFLC. Both were subjected to linear least square regression analysis.

\subsection{Accuracy}

The accuracy was assessed by carrying out recovery studies (standard addition method) for the proposed UV and RP-UFLC methods. For this, three different concentrations of Etanercept were prepared in triplicate at level of 50\%, 100\% and $150 \%$ of its predefined concentration $(50,100,150 \mu \mathrm{g} / \mathrm{mL})$. Accuracy was determined based on percent recovery.

\subsection{Precision}

Precision expresses the reproducibility of the measurements and is determined in terms of repeatability. It is analyzed by carrying out six independent assays of Etanercept solution (intra-day). Intermediate precision was analyzed by repeating same method on following three days. Both Intraday and Interday precision are expressed in terms of RSD \%.

\subsection{Robustness}

Robustness of analytical method is the capability of an optimized method to remain unchanged in its execution despite of slight, minimal changes in method parameters. Robustness of the developed UV method was obtained by changing 
wavelength $( \pm 1 \mathrm{~nm})$ and observing the absorbance whereas for RP-UFLC method it was assessed by changing flow rate by $\pm 0.1 \mathrm{ml}$ and slight variation in the optimized mobile phase ratio. The results were expressed in terms of RSD \%.

\subsection{Ruggedness}

Ruggedness of analytical method is the ability of a method to perform unaffected in presence of various external influences. Rugged analytical methods are given priority as they are free from influence of surrounding environmental factors. The UV and RP-UFLC method was carried out by analyzing Etanercept samples in triplicate and by utilizing two distinct instruments. The results were calculated in terms of RSD \%.

\subsection{LOQ and LOD}

For determining LOQ, following equation was used.

$$
\mathrm{LOQ}=10 \times \mathrm{SD} / \mathrm{S}
$$

For determining LOD, following equation was used.

$$
\mathrm{LOD}=3.3 \times \mathrm{SD} / \mathrm{S}
$$

where, $\mathrm{SD}=$ Standard deviation; $\mathrm{S}=$ Slope

\subsection{Assay of Etanercept Content in Marketed Formulation}

The proposed UV-Vis and RP-UFLC methods were promptly used for determination of Etanercept content in pharmaceutical marketed formulation. For the study, Etacept ${ }^{\circledR} 25 \mathrm{mg}$ injection was used and suitable dilution was made using double distilled water. The prepared marketed formulation samples were analyzed using optimized and validated methods.

\section{Results}

\subsection{Method Development and Optimization}

Determination of maximum absorbance is the first step for the analysis (quantitatively or qualitatively) by UV and RP-UFLC. Etanercept solution $(500 \mu \mathrm{g} / \mathrm{mL})$ was scanned using UV-Visible spectrophotometer (Figure 2). UV software processed full scan and the $\lambda_{\max }$ were identified with the help of software to be 215 $\mathrm{nm}$ for Etanercept.

\subsection{Preparation of Calibration Curve}

For quantitative analysis of Etanercept, six concentrations namely 5, 25, 50, 100, 150 and $200 \mu \mathrm{g} / \mathrm{ml}$ were used for developing calibration curve by UV. The absorbance of different calibration standards was measured at $215 \mathrm{~nm}$ using fixed wavelength mode of spectrophotometer. Absorbances of each concentration were analyzed in triplicate and for calibration curve the average of the absorbances were taken. Equation $y=0.0021 x+0.0046$ was obtained for the absorbance plotted against different concentrations of the drug (Figure 3). By RP-UFLC, Equation 


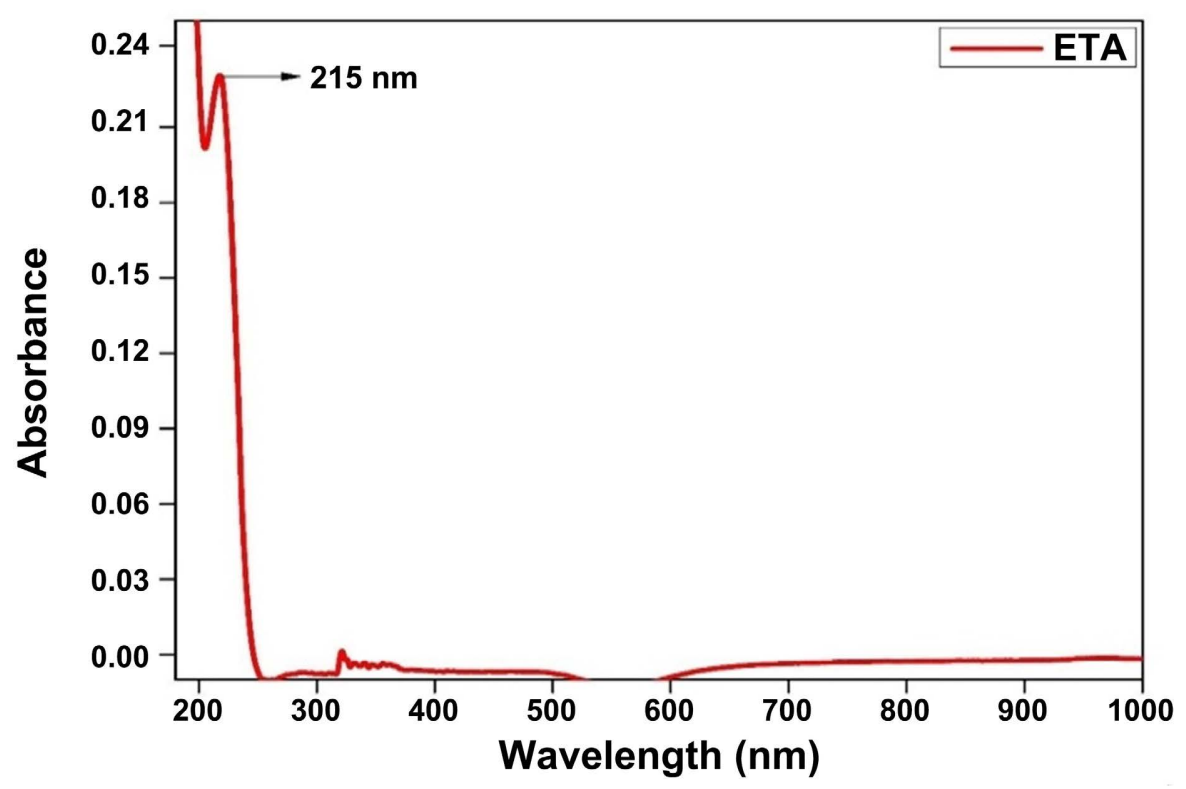

Figure 2. UV-visible spectra of Etanercept reference standard (ETA).

$y=83,337 x+45,060$ was obtained for the peak areas plotted against different concentrations (1, 2, 4, 8, 16 and $32 \mu \mathrm{g} / \mathrm{ml}$ ) (Figure 4).

\subsection{Method Validation}

\subsubsection{System Suitability}

As per the ICH guidelines, the theoretical plate number (greater than 2000 i.e., $6837(\mathrm{n}=6))$, Tailing factor $(<2$, i.e., $1.309(\mathrm{n}=6))$ and percentage relative standard deviation $(\leq 2 \%)$ were obtained and demonstrated that the method can generate the accurate and precise results with optimized conditions (Figure 5).

\subsubsection{Linearity and Range}

For UV analysis, Calibration curve of Etanercept covering a range of 5 to 200 $\mu \mathrm{g} / \mathrm{ml}$ was developed (Figure 3). Correlation coefficient value was found to be 0.999 for the calibration curve which yielded an equation, $y=0.0021 x+0.0046$ upon subjugation to least square regression analysis.

For RP-UFLC analysis, Calibration curve was in the range of 1 to $32 \mu \mathrm{g} / \mathrm{ml}$, with Linear equation found to be $y=83,337 x+45,060$. The regression coefficient was considered to be 0.9995 (Figure 4). Retention time was found to be $3.18 \pm$ $0.01 \mathrm{~min}$ (Figure 5). The linearity graph, disclosed that the developed methods are linear in the mentioned concentration range of calibration standards.

\subsubsection{Accuracy}

For UV and RP-UFLC methods for Etanercept analysis, accuracy was assessed using recovery studies. Range of mean recovery of Etanercept was found to be in between $99.8 \%$ to $100.38 \%$ (UV) and $99 \%$ to $100.166 \%$ (RP-UFLC) (Table 1). From the accuracy studies, it was revealed that developed UV and RP-UFLC methods are accurate as the RSD \% was below $2 \%$. 


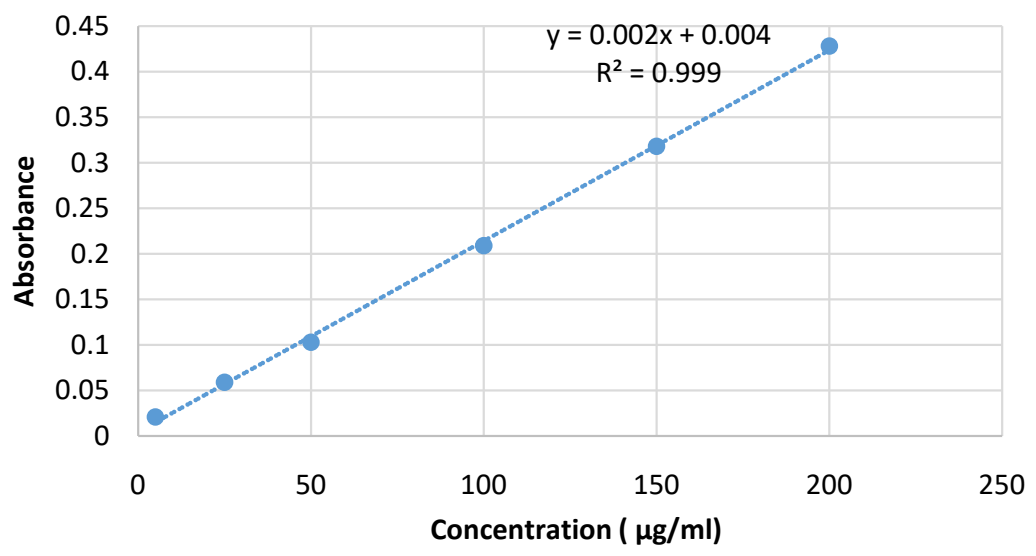

Figure 3. Calibration curve for Etanercept by UV spectroscopy.

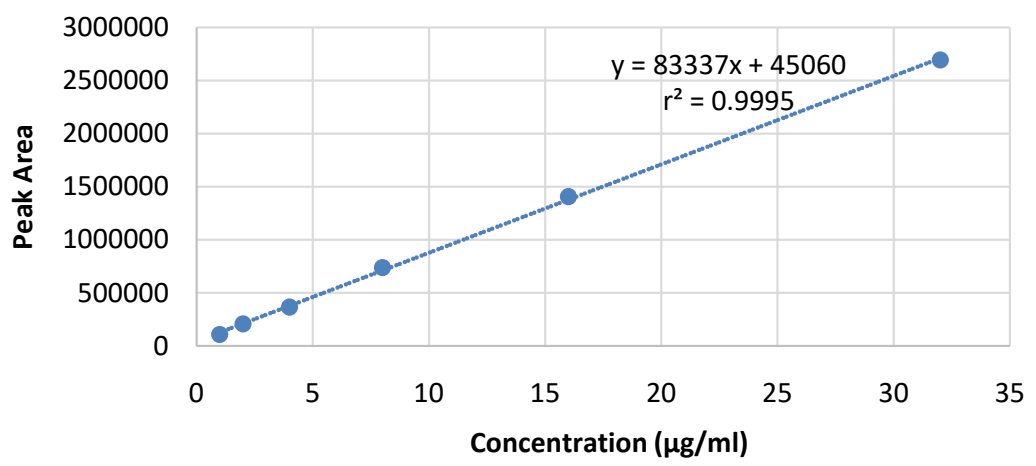

Figure 4. Calibration curve of Etanercept by RP-UFLC.

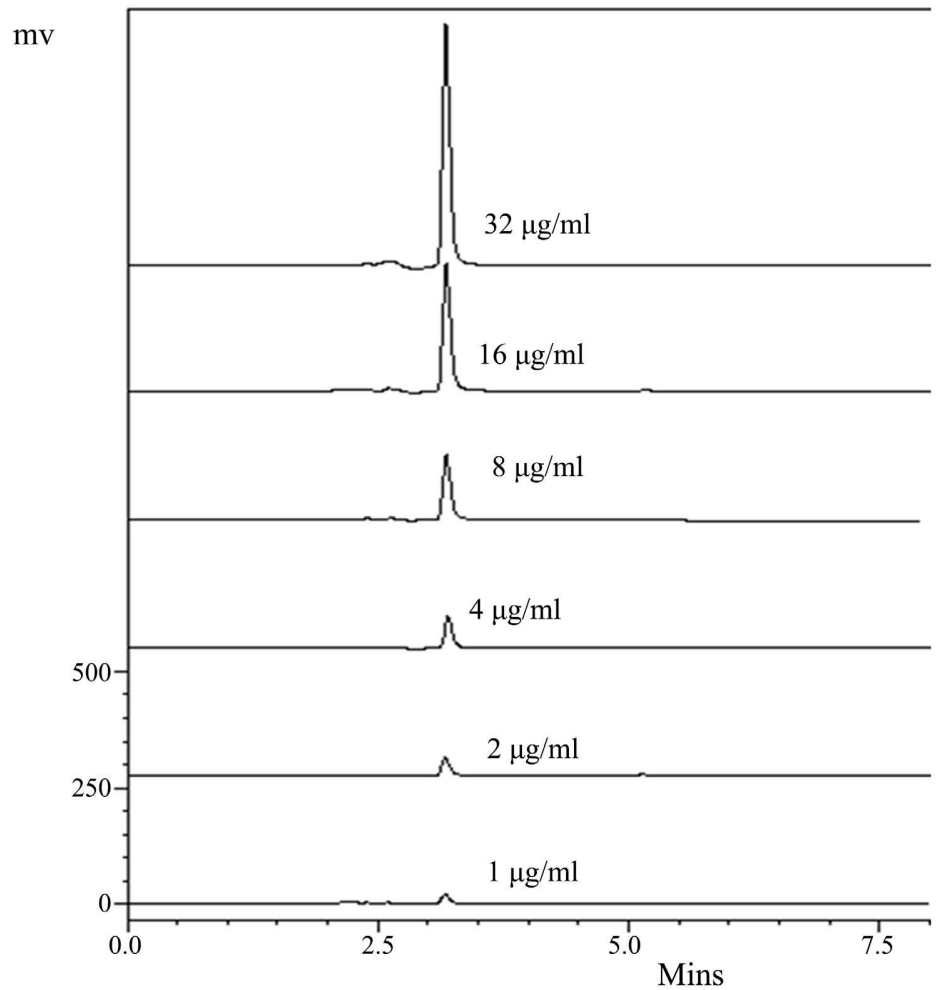

Figure 5. Chromatogram of Etanercept by RP-UFLC. 
Table 1. Accuracy data of Etanercept by UV spectrometer and RP-UFLC.

\begin{tabular}{|c|c|c|c|c|c|c|c|}
\hline \multirow{2}{*}{\multicolumn{2}{|c|}{ S. No. Conc. (\%) }} & \multicolumn{3}{|c|}{ UV Spectrometry } & \multicolumn{3}{|c|}{ RP-UFLC } \\
\hline & & $\%$ Recovery & \multirow{2}{*}{$\begin{array}{l}\text { Mean \% } \\
\text { Recovery }\end{array}$} & \multirow{2}{*}{ RSD \% } & Recovery \% & $\begin{array}{c}\text { Mean \% } \\
\text { Recovery }\end{array}$ & RSD \% \\
\hline 1 & 50 & 100.38 & & & 99.15 & & \\
\hline 2 & 50 & 101.34 & 100.38 & 1 & 98.4 & 99 & 0.43 \\
\hline 3 & 50 & 99.42 & & & 99.45 & & \\
\hline 4 & 100 & 100.1 & & & 99.375 & & \\
\hline 5 & 100 & 100.6 & 100.13 & 0.579 & 100.425 & 99.425 & 0.86 \\
\hline 6 & 100 & 99.71 & & & 98.475 & & \\
\hline 7 & 150 & 99.49 & & & 718,631 & & \\
\hline 8 & 150 & 99.8 & 99.8 & 0.581 & 710,353 & 100.166 & 0.69 \\
\hline 9 & 150 & 100.12 & & & 709,879 & & \\
\hline
\end{tabular}

\subsubsection{Precision}

Intra- and inter-day precision of developed methods were estimated at 25, 50 and $100 \mu \mathrm{g} / \mathrm{ml}$ levels of Etanercept for UV and 8, 16, $32 \mu \mathrm{g} / \mathrm{ml}$ for RP-UFLC. The results are presented in Table 2 and Table 3 and are explained by means of average/mean absorbance values, assay $\%$ and RSD $\%$ for the intra- and inter-day precision of both the methods. Inclusively, RSD \% values were found to be lower than 2 which showed that the results are as per the guidelines.

\subsubsection{Robustness}

Robustness of the proposed methods was established by analyzing at different temperatures, with slight variation in flow rates and mobile phase ratios. RSD \% values were found to be below 2 and in between 0.14 and 1.36 as shown in Table 4 and Table 5.

\subsubsection{Ruggedness}

Ruggedness was assessed by analyzing Etanercept solution in two different UV spectrophotometers (Table 6) and two different HPLC systems (Table 7). RSD \% values were between 0.27 and 0.84 . RSD \% was within the acceptable limits and also proposed that the methods were rugged.

\subsubsection{LOQ and LOD}

LOD and LOQ of proposed UV method was found to be 1.257 and $3.809 \mu \mathrm{g} / \mathrm{ml}$, respectively whereas LOD and LOQ of RP-UFLC method was found to be 0.1073 $\mu \mathrm{g} / \mathrm{ml}$ and $0.3251 \mu \mathrm{g} / \mathrm{ml}$, respectively. Lesser LOQ value indicated that optimized method can be suitably used for analyzing the samples containing even minimal quantities of Etanercept.

\subsubsection{Assay of Etanercept in Marketed Formulation}

The developed UV and RP-UFLC method were applied for the estimation of Etanercept content in Etacept ${ }^{\circledR} 25 \mathrm{mg}$ injection. Average percent assay of Etanercept 
Table 2. Precision data of Etanercept by UV spectroscopy.

\begin{tabular}{|c|c|c|c|c|c|c|c|c|c|c|}
\hline \multirow{3}{*}{ S. No. } & \multirow{3}{*}{$\begin{array}{l}\text { Conc. } \\
(\mu \mathrm{g} / \mathrm{ml})\end{array}$} & \multicolumn{9}{|c|}{ Intraday Precision } \\
\hline & & \multicolumn{3}{|c|}{ Morning } & \multicolumn{3}{|c|}{ Afternoon } & \multicolumn{3}{|c|}{ Evening } \\
\hline & & Mean & Assay \% & RSD \% & Mean & Assay \% & RSD \% & Mean & Assay \% & RSD \% \\
\hline 1 & 25 & 0.058 & 101.71 & 1.72 & 0.0573 & 100.38 & 1.01 & 0.0567 & 99.23 & 1.02 \\
\hline 2 & 50 & 0.109 & 99.42 & 0.92 & 0.110 & 100.38 & 0.91 & 0.1084 & 98.85 & 0.54 \\
\hline 3 & 100 & 0.215 & 100.19 & 0.47 & 0.2143 & 99.85 & 0.27 & 0.2137 & 99.57 & 0.27 \\
\hline \multicolumn{11}{|c|}{ Interday Precision } \\
\hline \multirow{2}{*}{ S. No. } & \multirow{2}{*}{$\begin{array}{l}\text { Conc. } \\
(\mu \mathrm{g} / \mathrm{ml})\end{array}$} & \multicolumn{3}{|c|}{ Day 1} & \multicolumn{3}{|c|}{ Day 2} & \multicolumn{3}{|c|}{ Day 3} \\
\hline & & Mean & Assay \% & RSD \% & Mean & Assay \% & RSD \% & Mean & Assay \% & RSD \% \\
\hline 1 & 25 & 0.0570 & 99.80 & 1.75 & 0.0570 & 99.80 & 1.75 & 0.0564 & 98.67 & 1.02 \\
\hline 2 & 50 & 0.1094 & 99.80 & 0.53 & 0.1090 & 99.42 & 0.92 & 0.1077 & 98.47 & 0.54 \\
\hline 3 & 100 & 0.2154 & 100.38 & 0.27 & 0.2147 & 100.04 & 0.27 & 0.2144 & 99.90 & 0.27 \\
\hline
\end{tabular}

Table 3. Precision data of Etanercept by RP-UFLC.

\begin{tabular}{|c|c|c|c|c|c|c|c|c|c|c|}
\hline \multicolumn{11}{|c|}{ Intraday Precision } \\
\hline \multirow{2}{*}{ S. No. } & \multirow{2}{*}{$\begin{array}{l}\text { Conc. } \\
(\mu \mathrm{g} / \mathrm{ml})\end{array}$} & \multicolumn{3}{|c|}{ Morning } & \multicolumn{3}{|c|}{ Afternoon } & \multicolumn{3}{|c|}{ Evening } \\
\hline & & Mean & Assay \% & RSD \% & Mean & Assay \% & RSD \% & Mean & Assay \% & RSD \% \\
\hline 1 & 8 & $712,954.34$ & 100.125 & 0.69 & 717218 & 100.75 & 0.23 & $716,060.67$ & 100.625 & 0.09 \\
\hline 2 & 16 & $1,402,589.67$ & 101.75 & 0.09 & $1,403,482.33$ & 101.875 & 0.04 & $1,402,693$ & 101.812 & 0.32 \\
\hline 3 & 32 & $2,694,083.33$ & 99.331 & 0.07 & $2,694,278.33$ & 99.312 & 0.07 & $2,694,393$ & 99.343 & 0.15 \\
\hline \multicolumn{11}{|c|}{ Interday Precision } \\
\hline \multirow{2}{*}{ S. No. } & \multirow{2}{*}{$\begin{array}{l}\text { Conc. } \\
(\mu \mathrm{g} / \mathrm{ml})\end{array}$} & \multicolumn{3}{|c|}{ Day 1} & \multicolumn{3}{|c|}{ Day 2} & \multicolumn{3}{|c|}{ Day 3} \\
\hline & & Mean & Assay \% & RSD \% & Mean & Assay \% & RSD \% & Mean & Assay \% & RSD \% \\
\hline 1 & 8 & $716,060.667$ & 100.625 & 0.16 & $717,248.33$ & 100.75 & 0.05 & $717,358.67$ & 100.837 & 0.05 \\
\hline 2 & 16 & $1,402,312.67$ & 101.75 & 0.05 & $1,401,464.67$ & 101.687 & 0.01 & $1,401,276.33$ & 101.687 & 0.06 \\
\hline 3 & 32 & $2,696,056$ & 99.406 & 0.1 & $2,695,367$ & 99.375 & 0.04 & $2,695,505.33$ & 99.384 & 0.12 \\
\hline
\end{tabular}

Table 4. Robustness data at different temperatures by UV spectroscopy.

\begin{tabular}{ccccc}
\hline S. No. Conc. $(\mu \mathrm{g} / \mathrm{ml})$ & Temperature & Absorbance & $\%$ RSD \\
\hline 1 & 200 & $25^{\circ} \mathrm{C}$ & 0.4277 & 0.14 \\
2 & 200 & $28^{\circ} \mathrm{C}$ & 0.4276 & 0.27 \\
\hline
\end{tabular}

Table 5. Robustness data of Etanercept by RP-UFLC.

\begin{tabular}{ccccccc}
\hline S. No. & $\begin{array}{c}\text { Conc. } \\
(\mu \mathrm{g} / \mathrm{ml})\end{array}$ & $\begin{array}{c}\text { Flow Rate } \\
(\mathrm{ml} / \mathrm{min})\end{array}$ & $\begin{array}{c}\text { Mobile Phase Ratio } \\
(\text { Buffer:ACN) }\end{array}$ & Rt & $\begin{array}{c}\text { Peak Area } \\
(\text { Mean })\end{array}$ & \% RSD \\
\hline 1 & 4 & 1 & $61: 39$ & 3.18 & 370,778 & 1.36 \\
2 & 4 & 1 & $59: 41$ & 3.17 & $366,232.34$ & 1.01 \\
3 & 4 & 0.9 & $60: 40$ & 3.18 & $3,666,373$ & 0.72 \\
4 & 4 & 1.1 & $60: 40$ & 3.19 & 356,159 & 0.95 \\
\hline
\end{tabular}


Table 6. Ruggedness data of UV method for Etanercept.

\begin{tabular}{ccccc}
\hline S. No. Conc. $(\mu \mathrm{g} / \mathrm{ml})$ & Instruments Used & Absorbance & \% RSD \\
\hline 1 & 100 & $\begin{array}{l}\text { UV 1800 Shimadzu } \\
\text { spectrophotometer }\end{array}$ & 0.2147 & 0.27 \\
2 & 100 & $\begin{array}{c}\text { Elico Double beam SL 210 UV } \\
\text { VIS spectrophotometer }\end{array}$ & 0.2144 & 0.27 \\
\hline
\end{tabular}

Table 7. Ruggedness data of RP-UFLC method for Etanercept.

\begin{tabular}{cccccc}
\hline S. No. & $\begin{array}{c}\text { Conc. } \\
(\mu \mathrm{g} / \mathrm{ml})\end{array}$ & Instruments Used & Rt & $\begin{array}{c}\text { Peak Area } \\
(\text { Mean })\end{array}$ & \% RSD \\
\hline 1 & 2 & $\begin{array}{c}\text { Shimadzu Prominence } \\
\text { LC-20AD UFLC system }\end{array}$ & 3.17 & 210,185 & 0.35 \\
2 & 2 & $\begin{array}{c}\text { Shimadzu LC 20 AD UFLC, } \\
\text { Diode array detector }\end{array}$ & 3.18 & 209,210 & 0.84 \\
\hline
\end{tabular}

in Etacept ${ }^{\circledR}$ injection as per UV and RP-UFLC methods were found to be $100.76 \%$ and $100.25 \%$, respectively which is within the acceptable limits set by ICH.

\section{Discussion}

Analysis of biologics involves the use of sophisticated and advanced analytical methods especially for comparing the innovator with the newly approved biosimilars. Analyzing the glycans [20], measurement of free and unoxidized thiols using 5,5'-dithionitrobenzoic acid (DTNB) and DyLight Maleimide (DLM) as derivatizing agents [21], detection of instability in Etanercept during thermal stress testing [17], physicochemical and clinical comparability followed by a clinical study [16] [18] [22] [23] [24], absolute quantification of oxidation in monoclonal antibodies and Fc-fusion proteins by UV and MS detection [25], etc. are to name a few intricate techniques used for comparisons. In collation with advanced technologies, UV and RP-UFLC methods can be used for quantitative analysis. Ultraviolet (UV) methods have the benefit of being simple, easy, rapid and cost-effective. In comparison to earlier reported work, the present RP-UFLC work deals with reliable and economic analysis of Etanercept. The optimized RP-UFLC method is evidenced to be less time-consuming (Rt $3.18 \pm 0.1 \mathrm{~min}$ with binary elution). Reported literature employed gradient time programmed elution whereas binary elution was used in the proposed method. Protein biologics from different manufacturers can be analyzed using the developed RP-UFLC method.

In conclusion, faster analysis time, increased sensitivity, and cost-effectiveness of these methods demonstrated that they are suitable for routine laboratory use. Simple, reliable, quick, economic, accurate, precise and sensitive methods were developed and validated as per ICH guideline. 


\section{Acknowledgements}

We are thankful to Cipla Limited, Mumbai, for sending Etacept ${ }^{\circledR}$ as a gift sample.

\section{Conflicts of Interest}

The authors declare no conflicts of interest regarding the publication of this paper.

\section{References}

[1] Nupur, N., Singh, S.K., Narula, G. and Rathore, A.S. (2016) Assessing Analytical Comparability of Biosimilars: GCSF as a Case Study. Journal of Chromatography $B$, 1032, 165-171. https://doi.org/10.1016/j.jchromb.2016.05.027

[2] Burness, C.B. and Duggan, S.T. (2016) Etanercept (SB4): A Review in Autoimmune Inflammatory Diseases. BioDrugs, 30, 371-378. https://doi.org/10.1007/s40259-016-0188-Z

[3] Scott, L.J. (2014) Etanercept: A Review of Its Use in Autoimmune Inflammatory Diseases. Drugs, 74, 1379-1410. https://doi.org/10.1007/s40265-014-0258-9

[4] Nast, A., Gisondi, P., Ormerod, A.D., Saiag, P., Smith, C., Spuls, P., et al. (2015) European S3-Guidelines on the Systemic Treatment of Psoriasis Vulgaris-Update 2015-Short Version-EDF in Cooperation with EADV and IPC. Journal of the European Academy of Dermatology and Venereology, 29, 2277-2294. https://doi.org/10.1111/jdv.13354

[5] Braun, J., van den Berg, R., Baraliakos, X., Boehm, H., Burgos-Vargas, R., Collantes-Estevez, E., et al. (2011) 2010 Update of the ASAS/EULAR Recommendations for the Management of Ankylosing Spondylitis. Annals of the Rheumatic Diseases, 70, 896-904. https://doi.org/10.1136/ard.2011.151027

[6] Gossec, L., Smolen, J.S., Ramiro, S., de Wit, M., Cutolo, M., Dougados, M., et al. (2016) European League against Rheumatism (EULAR) Recommendations for the Management of Psoriatic Arthritis with Pharmacological Therapies: 2015 Update. Annals of the Rheumatic Diseases, 75, 499-510. https://doi.org/10.1136/annrheumdis-2015-208337

[7] Minota, S. (2013) Physico-Chemical Characteristics of TNFa Blockers and Their Effectiveness in the Treatment of Rheumatoid Arthritis: The Theoretical and Real worlds. Modern Rheumatology, 23, 1034-1036. https://doi.org/10.3109/s10165-012-0744-4

[8] Strand, V., Girolomoni, G., Schiestl, M., Mayer, R.E., Friccius-Quecke, H. and McCamish, M. (2017) The Totality-of-the-Evidence Approach to the Development and Assessment of GP2015, a Proposed Etanercept Biosimilar. Current Medical Research and Opinion, 33, 993-1003. https://doi.org/10.1080/03007995.2017.1288612

[9] Smolen, J.S., Landewe, R., Breedveld, F.C., Buch, M., Burmester, G., Dougados, M., et al. (2014) EULAR Recommendations for the Management of Rheumatoid Arthritis with Synthetic and Biological Disease-Modifying Antirheumatic Drugs: 2013 Update. Annals of the Rheumatic Diseases, 73, 492-509. https://doi.org/10.1136/annrheumdis-2013-204573

[10] Smolen, J.S., Aletaha, D., Bijlsma, J.W.J., Breedveld, F.C., Boumpas, D., Burmester, G., et al. (2010) Treating Rheumatoid Arthritis to Target: Recommendations of an International Task Force. Annals of the Rheumatic Diseases, 69, 631-637. https://doi.org/10.1136/ard.2009.123919

[11] Neovius, M., Arkema, E.V., Olsson, H., Eriksson, J.K., Kristensen, L.E., Simard, J.F., 
et al. (2015) Drug Survival on TNF Inhibitors in Patients with Rheumatoid Arthritis Comparisons of Adalimumab, Etanercept and Infliximab. Annals of the Rheumatic Disease, 74, 354-360. https://doi.org/10.1136/annrheumdis-2013-204128

[12] Goffe, B. and Cather, J.C. (2003) Etanercept: An Overview. Journal of the American Academy of Dermatology, 49, 105-111. https://doi.org/10.1016/mjd.2003.554

[13] Chiran, D.A., Litscher, G., Weber, M., Ailioaie, L.M., Ailioaie, C. and Litscher, D. (2013) Intravenous Laser Blood Irradiation Increases Efficacy of Etanercept in Selected Subtypes of Juvenile Idiopathic Arthritis: An Innovative Clinical Research Approach. Evidence-Based Complementary and Alternative Medicine, 2013, Article ID: 168134. https://doi.org/10.1155/2013/168134

[14] Lamanna, W.C., Mayer, R.E., Rupprechter, A., Fuchs, M., Higel, F., Fritsch, C., Vogelsang, C., Seidl, A., Toll, H., Schiestl, M. and Holzmann, J. (2017) The StructureFunction Relationship of Disulfide Bonds in Etanercept. Scientific Reports, 7, Article No. 3951. https://doi.org/10.1038/s41598-017-04320-5

[15] Campanati, A., Diotallevi, F., Martina, E., Paolinelli, M., Radi, G. and Offidani, A. (2020) Safety Update of Etanercept Treatment for Moderate to Severe Plaque Psoriasis. Expert Opinion on Drug Safety, 19, 439-448. https://doi.org/10.1080/14740338.2020.1740204

[16] Cho, I.H., Lee, N., Song, D., Jung, S.Y., Bou-Assaf, G., Sosic, Z., Zhang, W. and Lyubarskaya, Y. (2016) Evaluation of the Structural, Physicochemical, and Biological Characteristics of SB4, a Biosimilar of Etanercept. $m A b s, 8,1136-1155$. https://doi.org/10.1080/19420862.2016.1193659

[17] Maarschalkerweerd, A.V., Wolbink, G.J., Stapel, S.O., Jiskoot, W. and Hawe, A. (2011) Comparison of Analytical Methods to Detect Instability of Etanercept during Thermal Stress Testing. European Journal of Pharmaceutics and Biopharmaceutics, 78, 213-221. https://doi.org/10.1016/j.ejpb.2011.01.012

[18] Yamanaka, H., Kamatani, N., Tanaka, Y., Hibino, T., Drescher, E., Sánchez-Bursón, J., Rettenbacher, M., Bhatia, G., Gadve, S., Shah, C. and Bakhle, D. (2020) A Comparative Study to Assess the Efficacy, Safety, and Immunogenicity of YLB113 and the Etanercept Reference Product for the Treatment of Patients with Rheumatoid Arthritis. Rheumatology and Therapy, 7, 149-163.

https://doi.org/10.1007/s40744-019-00186-3

[19] European Directorate for the Quality of Medicines (2019) European Pharmacopoeia 10.0: Etanercept. Stationery Office, Strasbourg, 2566-2570.

[20] Houel, S., Hilliard, M., Yu, Y.Q., McLoughlin, N., Martin, S.M., Rudd, P.M., Williams, J.P. and Chen, W. (2014) N- and O-glycosylation Analysis of Etanercept Using Liquid Chromatography and Quadrupole Time-of-Flight Mass Spectrometry Equipped with Electron-Transfer Dissociation Functionality. Analytical Chemistry, 86, 576-584. https://doi.org/10.1021/ac402726h

[21] Victor, P.M.M., Abad-Javier, M.E., Romero-Díaz, A.J., Villaseñor-Ortega, F., Pérez, N.O., Flores-Ortiz, L.F. and Medina-Rivero, E. (2014) Comparability of a Three-Dimensional Structure in Biopharmaceuticals Using Spectroscopic Methods. Journal of Analytical Methods in Chemistry, 2014, Article ID: 950598. https://doi.org/10.1155/2014/950598

[22] Yi, S., Kim, S.E., Park, M.K., Yoon, S.H., Cho, J.Y., Lim, K.S., Shin, S.G., Jang, I.J. and Yu, K.S. (2012) Comparative Pharmacokinetics of HD203, a Biosimilar of Etanercept, with Marketed Etanercept $\left(\right.$ Enbrel $\left.^{\oplus}\right)$ : A Double-Blind, Single-Dose, Crossover Study in Healthy Volunteers. BioDrugs, 26, 177-184.

https://doi.org/10.2165/11631860-000000000-00000

[23] Miranda-Hernández, M.P., López-Morales, C.A., Perdomo-Abúndez, F.C., Sala- 
zar-Flores, R.D., Ramírez-Ibanez, N.D., Pérez, N.O., Pérez, A.M., Revilla-Beltri, J., Flores-Ortiz, L.F. and Medina-Rivero, E. (2016) New Alternatives for Autoimmune Disease Treatments: Physicochemical and Clinical Comparability of Biosimilar Etanercept. Journal of Immunology Research, 2016, Article ID: 9697080.

https://doi.org/10.1155/2016/9697080

[24] Richter, O.V., Skerjanec, A., Afonso, M., Heinrich, S.S., Poetzl, J., Woehling, H., Velinova, M., Koch, A., Kollins, D., Macke1, L. and Wuerth, G. (2017) GP2015, a Proposed Etanercept Biosimilar: Pharmacokinetic Similarity to Its Reference Product and Comparison of Its Autoinjector Device with Prefilled Syringes. British Journal of Clinical Pharmacology, 83, 732-741. https://doi.org/10.1111/bcp.13170

[25] Christof, F., Wohlschlager, T., Holzmann, J. and Huber, C.G. (2017) A Generic HPLC Method for Absolute Quantification of Oxidation in Monoclonal Antibodies and FC-Fusion Proteins Using UV and MS Detection. Analytical Chemistry, 89, 8391-8398. https://doi.org/10.1021/acs.analchem.7b01755 